\title{
Modeling Groundwater Potential Zones across Sulaimani Governorate Using Geographic Information System and Multi-influencing Factor Techniques
}

\author{
Haveen Muhammed Rashid* \\ Department of Water Resources, College of Engineering, University of Sulaimani, KRG, Iraq
}

\section{A B S T R A C T}

Groundwater is one of the most important natural resources in the world. The presence of groundwater is the result of interaction of several factors such as: hydrology, geology, climate, ecology, and physiography. The purpose of this paper is to produce groundwater potential zones which are useful in determining the amount of groundwater available in Sulaimani Governorate, North of Iraq. Geographic information system database for six different thematic layers (digital elevation model, rainfall, soil texture, drainage density, slope and land use/land cover) were generated. The study approach involved integration of six layers carried out based on the multiplication of each data raster values with specific weight using weighted overlay analysis method. Raster maps of all the layers assigned a fixed score and weight using multiinfluencing factor technique. Based on the resulted map the study area has been divided into four zones that had very high potential zone (1\%), high potential zone (14\%), moderate zone potential $(79 \%)$ and low potential zone $(6 \%)$. About $50 \%$ of the high groundwater potential zone were located in Halabja, Rania, and Pshdar districts. Obtained results can be useful for exploration in regional areas, preventing excessive exploitation of groundwater and planning for suitable sites of artificial groundwater.

Index Terms: Geographic information system, Groundwater potential, Multi-influencing factor, Sulaimani, Spatial distribution

\section{INTRODUCTION}

Groundwater is a substantial source of freshwater; however, it does not always available sufficiently where it is needed. Population growth, industry development and climate change increased demand of fresh water, which causes the decline of groundwater table [1]. Therefore, the lower availability of

\begin{tabular}{|l|l|}
\hline Dol:10.21928/uhdjst.v5n1y2021.pp13-20 & E-ISSN: 2521-4217 \\
P-ISSN: 2521-4209
\end{tabular}

Copyright ( 2021 Rashid. This is an open access article distributed under the Creative Commons Attribution Non-Commercial No Derivatives License 4.0 (CC BY-NC-ND 4.0) groundwater by side of increase in its development, require sustainable groundwater management [2] and [3].

Geographic information system (GIS) and remote sensing are the two mechanisms that have been used remarkably in groundwater management researches. GIS is widely used for modeling process by preparing the input parameter for the model through generation of digital geographic database [4]. Assessment of groundwater resources of an area requires preparation and integration of many factors such as: slope, drainage, land use (LU), rainfall, elevation, soil texture, geological structures and geomorphic features [4]. Integration of various geospatial information is carried out by taking values of each data raster and multiplying them

Corresponding author's e-mail: Haveen Muhammed Rashid, Department of Water Resources, College of Engineering, University of Sulaimani, Kurdistan Region - F.R. Iraq. E-mail: haveen.rashid@univsul,edu.iq

Received: 10-11-2020

Accepted: 11-02-2021

Published: 15-02-2021 
with the specific weight. Weights determination is intuitive and is obtained from the values used in the literatures or from the experience.

Many researches were studied this issue utilizing both GIS and remote sensing techniques [5]-[17]. In 2012 Jani published a research used GIS to model groundwater flow for the aquifer called Lincolnshire Limestone in the Slea catchment, United Kingdom. The resulted model has confirmed the advantage of using GIS tool in modeling groundwater [2].

Rawal and Vyas (2016) presented a research to delimit the water logging in Mehsana district, India using GIS application in groundwater modeling and identify the perched aquifers in their selected area. Their study used factors such as soil layer, LU layer, and the temporal distribution of water logging. The resulted model suggests convenient method to control water logging and identifies the groundwater regime to estimates the total recharge [18].

In a study conducted by Singh, GIS techniques were used to identify the recharge zones of groundwater in New Zealand. Many data sets were prepared such as soil layer, LU layer, aspect, slope, lithology, and drainage density with $500 \mathrm{~m} \times$ $500 \mathrm{~m}$ spatial resolution. The data set overlies to develop potential zones of the groundwater. The output results explain; the groundwater has low potential in both residential and high elevation areas, while areas of water body and low elevations fall in the high potential zones [19].

Western Ghats river basin/India was selected to demonstrate the groundwater model. To delineate groundwater zones, 12 layers were utilized such as geology, drainage density layer, rainfall, soil, slope, geomorphology, lineament density, LU/ land cover [LC], roughness, topographic position index, topographic wetness index, and curvature. The relative weights to each class in all maps were allocated using Analytical Hierarchy Process [20].

Karim and Al-Manmi selected Halabja Said Sadiq sub-basin as a study area to model the groundwater recharge zones using GIS and geophysical mechanisms. Eight thematic maps were used such as hydrogeology, LU/LC, topography, drainage density, lineaments, soil type, slope, and rainfall with four geoelectrical resistivity profiles. Three zones of groundwater potential delineated which are low, moderate and high and cover $33 \%, 24 \%$, and $42 \%$ of the total area, respectively. Spatially, the highest zone is located along with the Quaternary deposits which characterized by high lineament density, low slop, and pediment deposition [13].
Groundwater recharge zones in a tropical river basin of Kerala, India were identified using integration of different layers. Ten thematic layers were prepared for mapping groundwater recharge. Four classes have been identified and approximately half of the basin area is located in two recharge zones; very high and high zones which are appropriate for groundwater recharge [3].

\section{STUDY AREA}

The proposed study area is located in Sulaimani Governorate, north of Iraq - Kurdistan Region, as shown in Fig. 1. According to the topographic map, the elevation is ranged from 182 to $3430 \mathrm{~m}$. The latitudes are between (34 $32^{\circ}$ $15^{\prime \prime} \mathrm{N}$ and $36^{\circ} 34^{\prime} 15^{\prime \prime} \mathrm{N}$ ), and the longitudes are between $\left(44^{\circ} 30^{\prime} 30 \mathrm{E}\right.$ and $\left.46^{\circ} 20^{\prime} 30 \mathrm{E}\right)$. The total area calculated as $18,525 \mathrm{~km}^{2}$ and the average annual rainfall of the study area is $(618 \mathrm{~mm})$ for 15 years from 2000 to 2014 taken from 14 metrological stations distributed within the proposed area. The study area has hot and cold weather in summer and winter, respectively, with long summer and winter season in compare to spring and autumn season [21], [22].

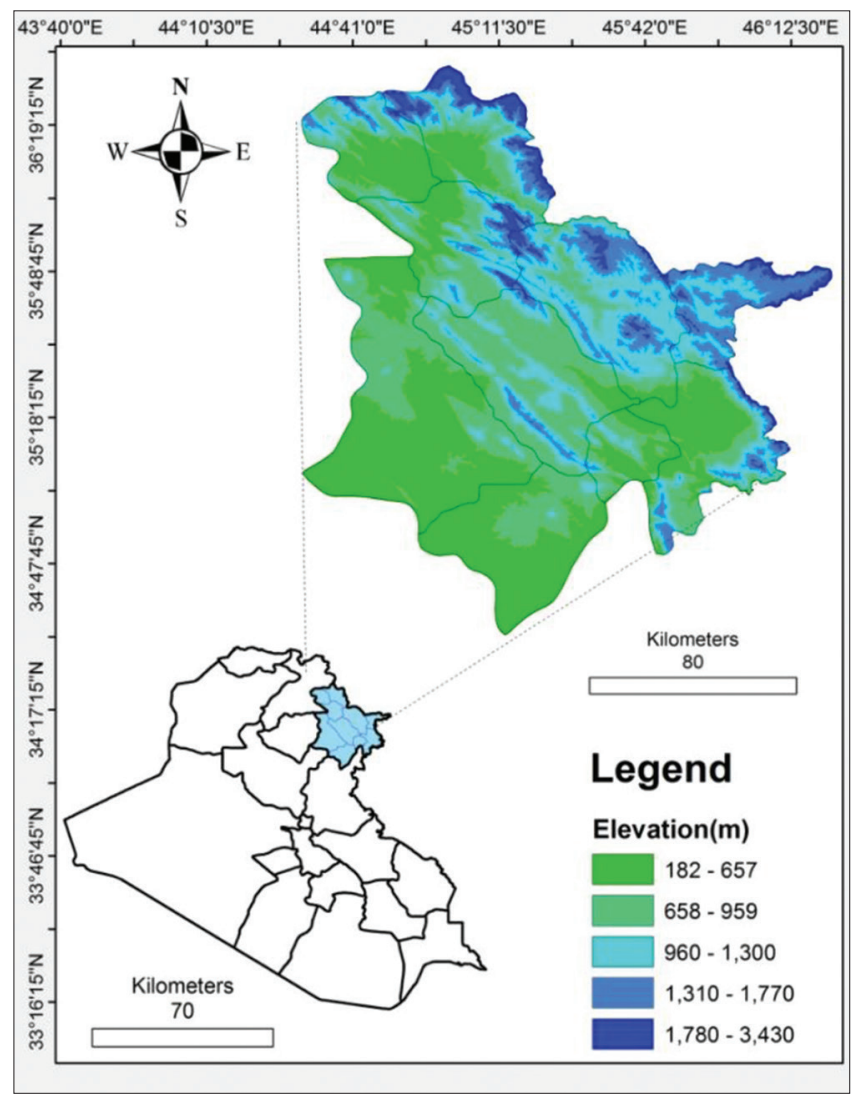

Fig. 1. Study area location and digital elevation model. 


\section{MATERIALS AND METHODS}

Different factors (layers) were used for the modeling process. Selection of factors was based on data availability across Sulaimani Governorate. The data were collected from various sources and include: Digital Elevation Model (DEM), soil texture, LU/LC, rainfall, slope, and drainage density. All the raster layers were projected using Universal Transverse Mercator UTM Projection Zone 38, Datum WGS84 with $30 \times 30 \mathrm{~m}$ resolution.

The method used in this study consists two main steps: (a) Geospatial database generation, (b) generation of weight for groundwater prospecting factors and associated features. The complete process of the groundwater potential zone delineation is shown as flowchart in Fig. 2. All the factors prepared for the current study and their impact on the occurrence of groundwater in Sulaimani are illustrated below:

\subsection{DEM}

The DEM data for Sulaimani as shown in Fig. 1 with elevations ranged from (182 to $3430 \mathrm{~m}$ ) classified into five classes spatially distributed in the area as $(35 \%, 31 \%, 19 \%$, $12 \%$, and $4 \%$ ) from low to high elevations. The data were downloaded from USGS earth explorer website using Shuttle Radar Topography Mission1 Arc Second-Global [23].

\section{2. $\mathrm{LU} / \mathrm{LC}$}

LC marks the physical land type such as water or forest; however, the LU provides information how people are using the land [24]. LULC gives the primary information on infiltration, soil moisture, surface water, and groundwater, additionally to give a signal on groundwater demand [25]-[29].

The LU map was created through image processing of remote sensing data using Arc GIS software (Iso Cluster Unsupervised Classification), by downloading 3 Landsat8 images (acquired on October 2019) with 7 bands for each image [23]. The study area was classified to 5 classes of LU/ LC: Water, Forest, Crop, Urban area, and Bare Soil which is shown in Fig. 3.

\subsection{Soil Map}

Soil properties influence groundwater recharge. The soils with coarse texture has high permeability which increase's groundwater recharge, while fine texture soils with low permeability decrease the groundwater recharge [30]. Therefore, soil properties such as permeability, porosity, texture, and structure have considerable effect on groundwater recharge [3] and [31].

The soil map of Sulaimani area was designed and classified to 5 classes based on percent of fine and course aggregates (soil texture) as shown in Fig. 4. This map shows the distribution of the soil texture in the study area as: (Sandy Loam 1\%, Clay 17\%, Loam 36\%, Sandy clay $9 \%$, and Sandy Clay Loam 37\%). The major soil types in the study area were grouped as: (Leptosol LP, Vertisol VR, Calcisol CL, and Gypsisol GY) [32]. The data were

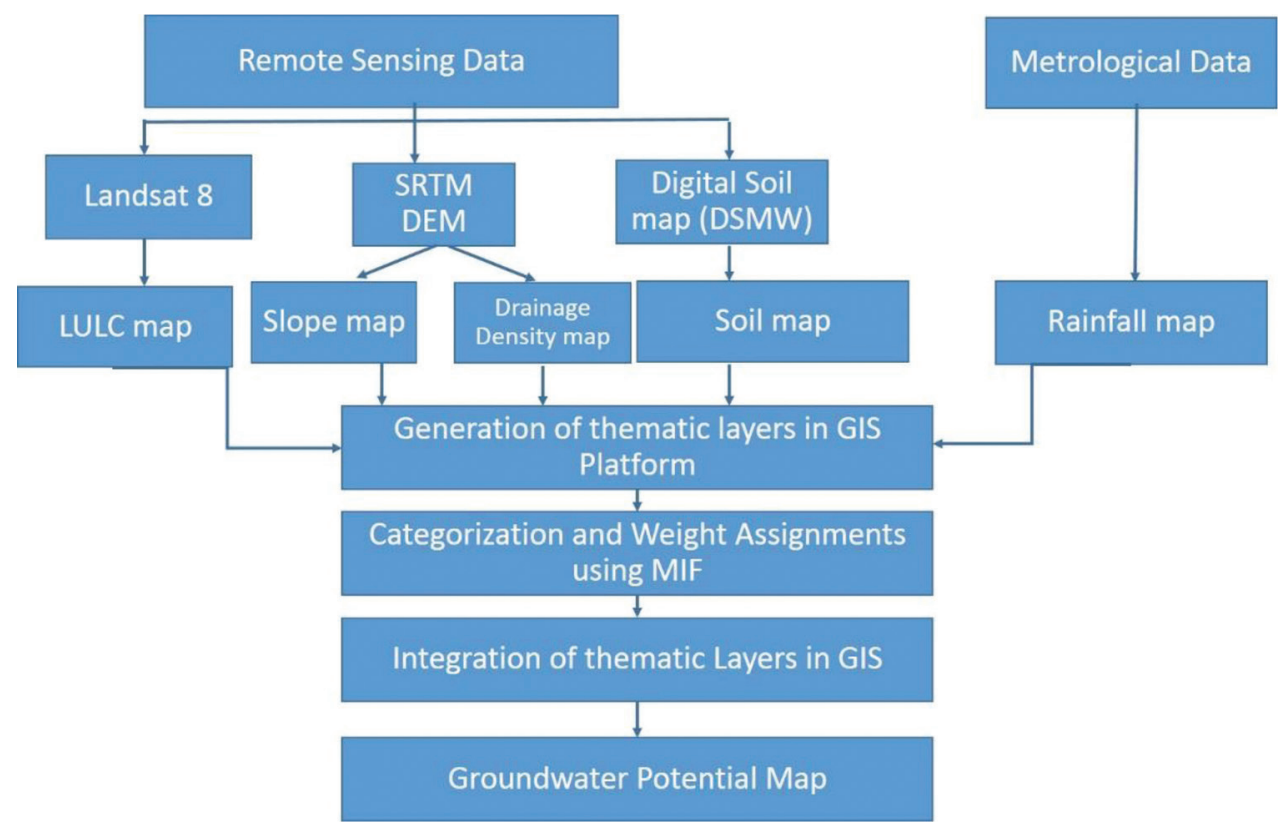

Fig. 2. Flowchart for delineating groundwater potential. 


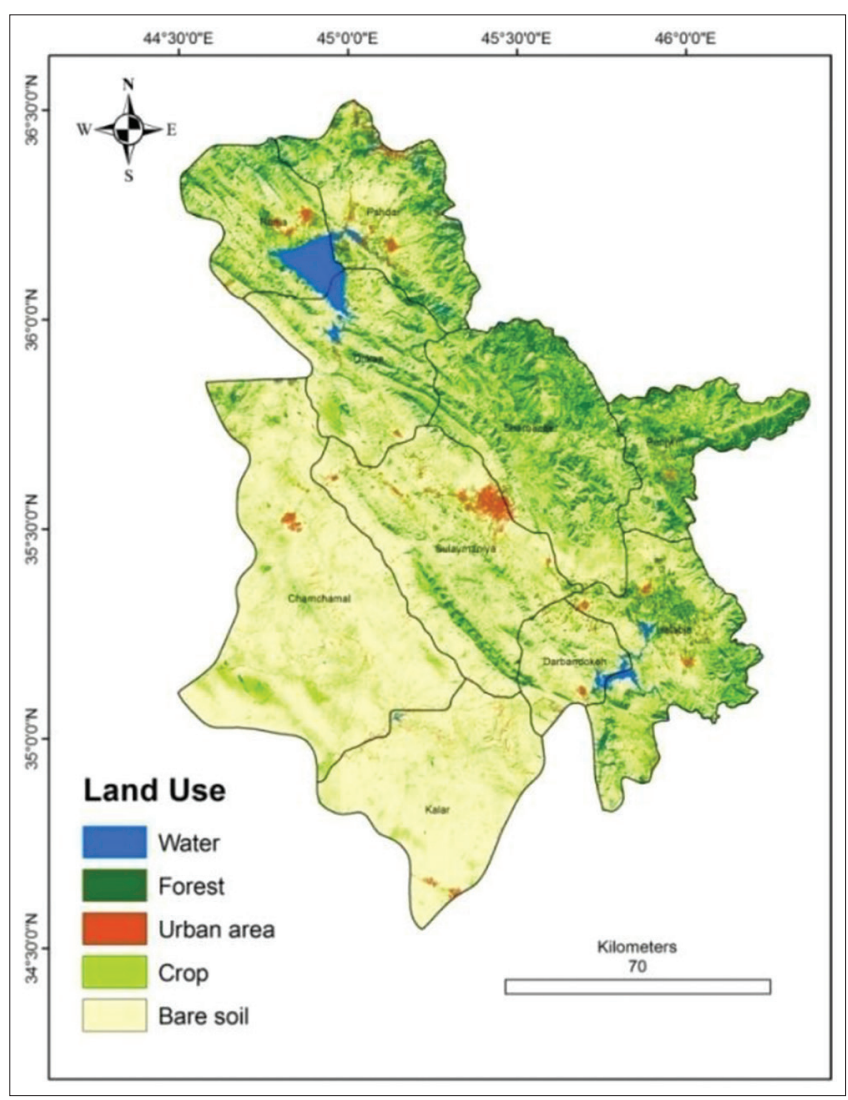

Fig. 3. Land use/land cover of the study area.

downloaded from the FAO-UNESCO Soil Map of the World and the present version is (3.6) of the digitized Soil Map of the World [33].

\subsection{Rainfall Map}

The groundwater recharge is remarkably affected by patterns of rainfall during recharge seasons [34], [35]. The average annual rainfall for the 14 stations from 2000 to 2014 in Sulaimani is represented in Fig. 5a. Rainfall map was created by Arc GIS utilizing Inverse Distance Weighted interpolation method with 5 classes in which each class represent different ranges of rainfall distributed as $(22 \%, 21 \%, 27 \%, 23 \%$, and $7 \%$ ) from low to high ranges shown in Fig. $5 \mathrm{~b}$.

\subsection{Slope Map}

The slope map was prepared from the DEM using 5 classes in degree and the spatial distribution in the study area are (very low slope $42 \%$, low slope $26 \%$, moderate slope $17 \%$, high slope 11\%, and very high slope 3\%) as shown in Fig. 6. Slope plays a notable effect on groundwater flow. The slope is considered as an essential factor for runoff generation due to its control of the division of precipitation into runoff and infiltration. A higher slope results in low recharge and

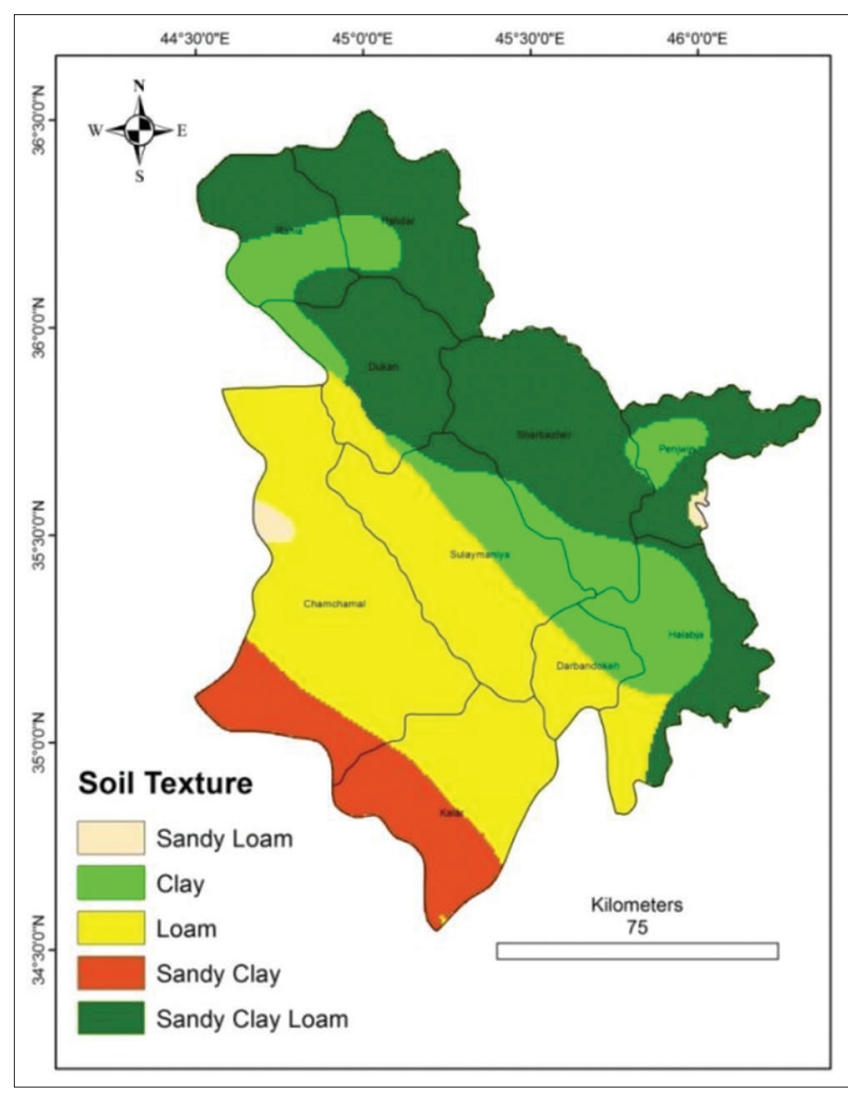

Fig. 4. Soil texture map of the study area.

fast runoff. Hence, the slope is inversely correlated with groundwater potential [8], [36]-[39].

\subsection{Drainage Density}

Drainage density can be calculated by taking the ratio of total length of all the streams in a drainage basin to the total area of the basin [40]. The drainage density has a reciprocal relation with the permeability. Drainage density with high values produces less permeability whereas low drainage density shows the areas of high permeability. Accordingly, it is a significant factor for modeling the groundwater potential zone [20]. Drainage density is calculating using the equation below [27]:

$$
\text { Drainage density }=\frac{\text { total length channels }(\mathrm{km})}{\text { basin area }\left(\mathrm{km}^{2}\right)}
$$

Map of the drainage density (Fig. 7) was generated using ArcGIS tool called line density analysis and 5 classes have been identified ranged between $\left(0.21\right.$ and $\left.2.9 \mathrm{~km} / \mathrm{km}^{2}\right)$.

\subsection{Multi-influencing Factors (MIF)}

Six factors, namely, DEM, LU/LC, soil texture, rainfall, slope, and drainage density have been specified to model the 


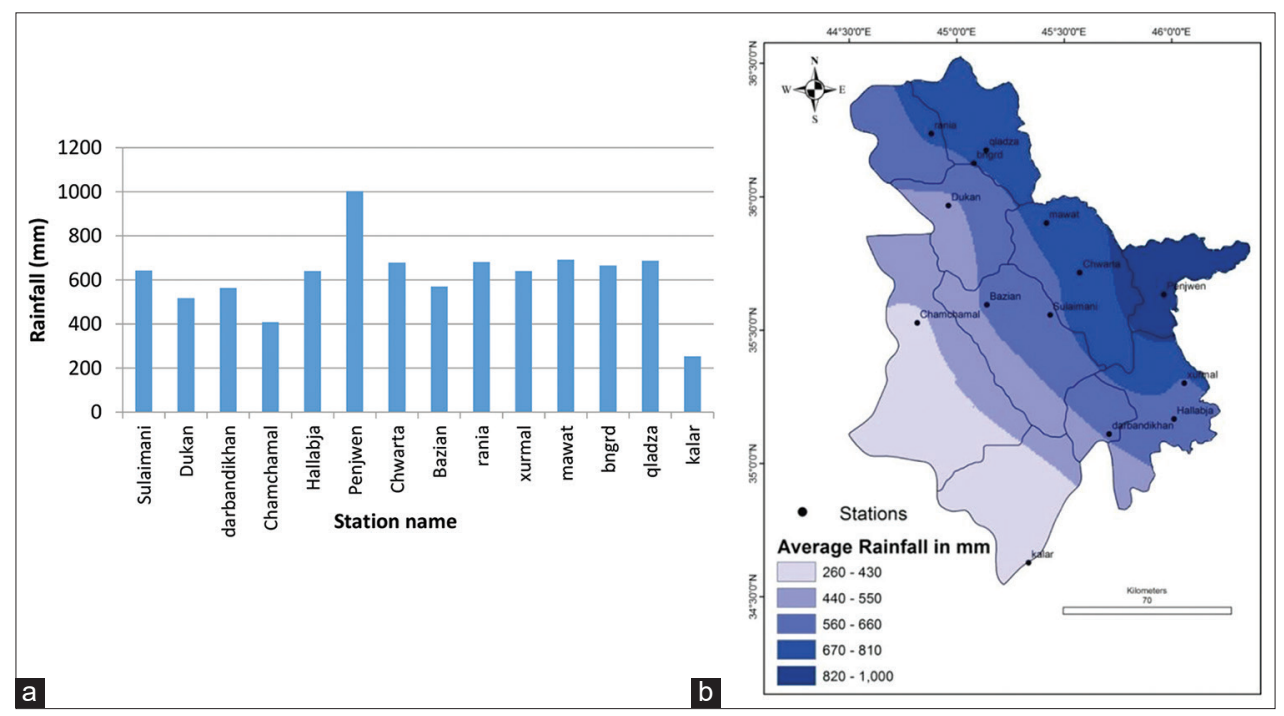

Fig. 5. (a). Average annual rainfall histogram of the stations. (b) Rainfall map of the study area.

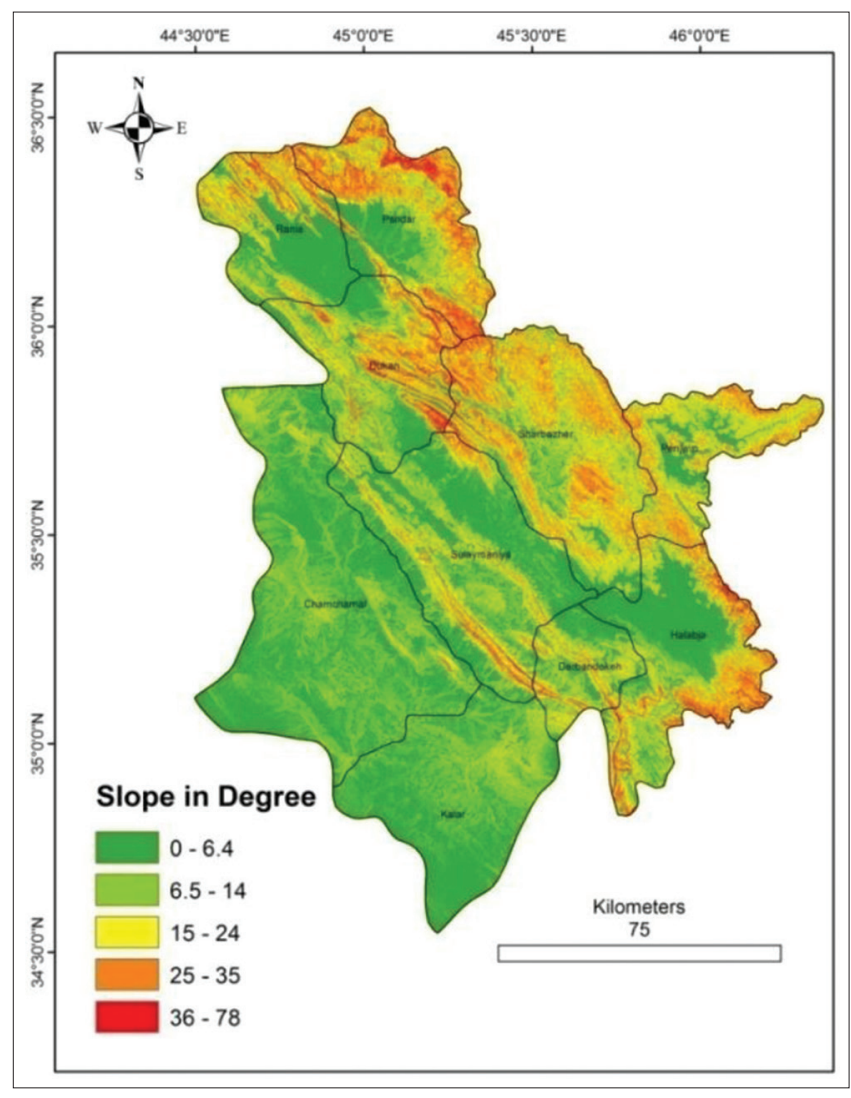

Fig. 6. Slope of the study area.

groundwater recharge potential zones. The mutual relations between these factors and their effect are shown in Fig. 8. These factors are interdependent and their influence on the recharge potential of groundwater has been estimated using

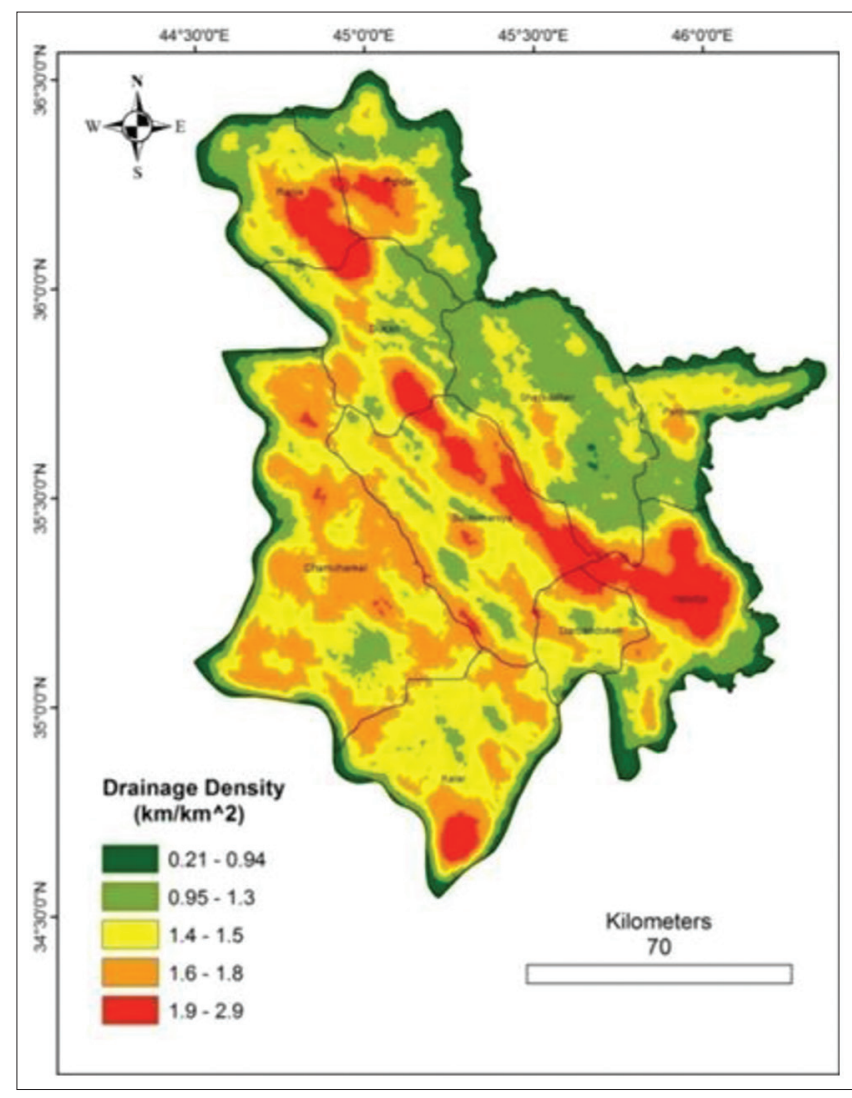

Fig. 7. Drainage density of the study area.

MIF technique. The major $\left(M_{j}\right)$ and minor $(M n)$ effects of the factors are designated as a numerical value of 1.0 and 0.5 , respectively (Table 1). The selected weight for all factors has been calculated using the following equation: 
TABLE 1: Effect of the impacting factor, relative rates, and proposed weight using MIF technique (modified after [3], [39], [41])

\begin{tabular}{lcccc} 
Factor & $\begin{array}{c}\text { Major } \\
\text { effect (Mj) }\end{array}$ & $\begin{array}{c}\text { Minor } \\
\text { effect }(\mathbf{M n})\end{array}$ & $\begin{array}{c}\text { Proposed relative } \\
\text { rates (Mj+Mn) }\end{array}$ & $\begin{array}{c}\text { Proposed weight for each impacting } \\
\text { factor }\end{array}$ \\
\hline DEM & $1+1$ & 0.5 & 2.5 & 21 \\
LULC & $1+1$ & 0.5 & 2.5 & 21 \\
Soil Texture & 1 & 0 & 1 & 8 \\
Rainfall & 1 & $0.5+0.5$ & 2 & 17 \\
Slope & $1+1$ & 0.5 & 2.5 & 21 \\
Drainage Density & 1 & 0.5 & 1.5 & 12 \\
Total $(\Sigma)$ & & & 12 & 100 \\
\hline
\end{tabular}

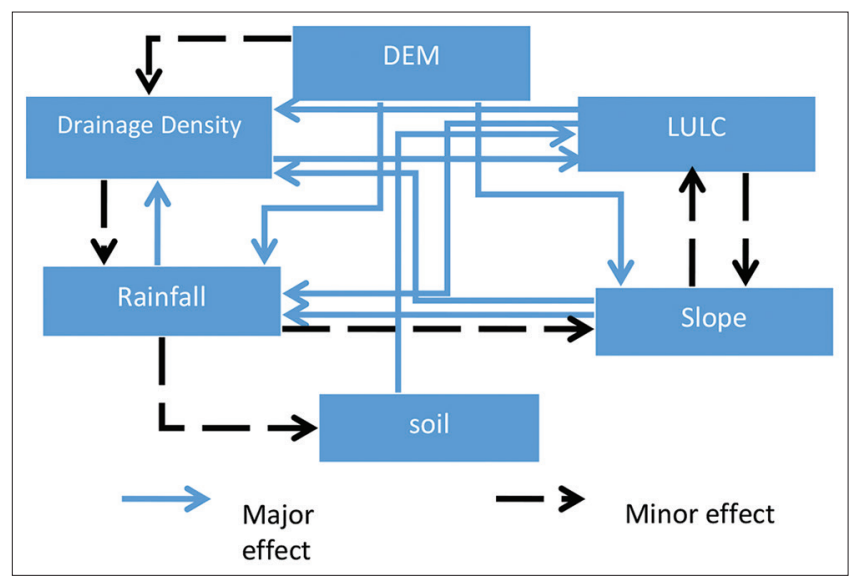

Fig. 8. Mutual relations between all the factors influencing the groundwater potential zone.

$$
\text { Proposed weight }=\frac{(M j+M n)}{\left(\sum M j+M n\right)} X 100
$$

\subsection{Layers Overlay}

The Weighted Overlay tool in Arc GIS was used for creating the potential groundwater zones in Sulaimani from the generated raster maps. The characteristics of each of the raster maps used in this study were gave weight age of $1-5$, depending on the layers effect on the occurrence of groundwater. The weight age factor 1 indicates low groundwater potentiality and 5 indicates high groundwater potentiality. The classifications of weighted factors impacting the potential zones are shown in Table 2 .

\section{RESULTS AND DISCUSSION}

Based on the assignment of all layers influence and weight of the individual features of the thematic layers, a potential groundwater zone map was produced as shown in Fig. 9. According to the results, about $79 \%\left(14423.45 \mathrm{~km}^{2}\right)$ of the study area can be classified as moderate groundwater recharge

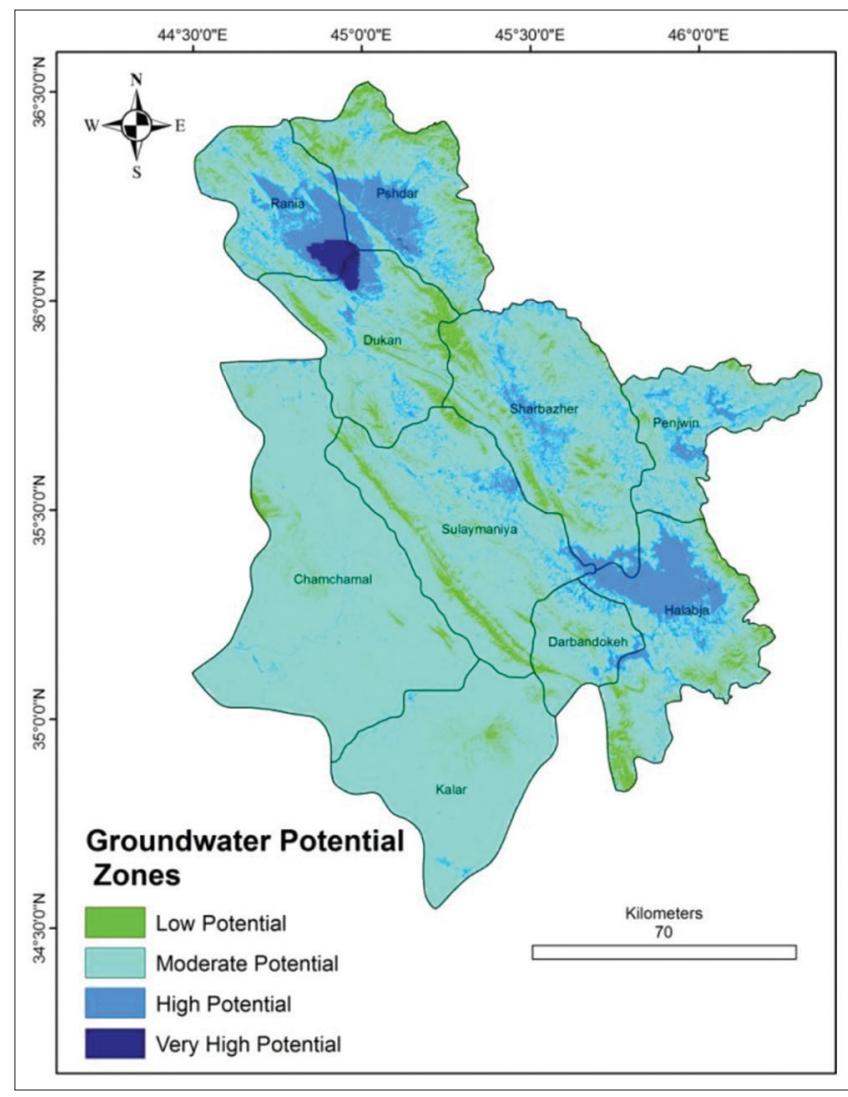

Fig. 9. Groundwater potential zones.

zone. About 1\% (112.3746 $\left.\mathrm{km}^{2}\right)$ has very high groundwater potential zone and about 14\% $\left(2576.78 \mathrm{~km}^{2}\right)$ has high groundwater potential zone, while only $6 \%\left(1168.015 \mathrm{~km}^{2}\right)$ of the total study area is of low groundwater potentials. Based on Fig. 8 , the high groundwater potential zones were covers about $50 \%$ of Halabja, Rania, Pshdar districts.

The results showed that the higher the elevations the less the groundwater potential, and in lower elevations the groundwater is more as the water accumulates in low lands. For slope arrangement, it shows that areas with steep slopes 
TABLE 2: Classification of weight age influencing the potential zones

\begin{tabular}{|c|c|c|c|}
\hline Factor & $\begin{array}{c}\text { Influence } \% \\
\text { (proposed weight) }\end{array}$ & $\begin{array}{l}\text { Factotr of } \\
\text { effect }\end{array}$ & $\begin{array}{l}\text { Weight } \\
\text { age }\end{array}$ \\
\hline \multirow{5}{*}{ DEM (m) } & 21 & $182-657$ & 5 \\
\hline & & $658-959$ & 4 \\
\hline & & $960-1300$ & 3 \\
\hline & & $1310-1770$ & 2 \\
\hline & & $1780-3430$ & 1 \\
\hline \multirow[t]{5}{*}{ Land use } & 21 & Water & 5 \\
\hline & & Forest & 2 \\
\hline & & Crop & 4 \\
\hline & & Urban area & 3 \\
\hline & & Bare soil & 1 \\
\hline \multirow[t]{5}{*}{ Soil texture } & 8 & Sandy clay loam & 1 \\
\hline & & Clay & 2 \\
\hline & & Loam & 4 \\
\hline & & Sandy Loam & 5 \\
\hline & & Sandy clay & 3 \\
\hline Rainfall & 17 & $260-430$ & 1 \\
\hline \multirow[t]{4}{*}{ (in $\mathrm{mm}$ ) } & & $440-550$ & 2 \\
\hline & & $560-660$ & 3 \\
\hline & & $670-810$ & 4 \\
\hline & & $820-1000$ & 5 \\
\hline \multirow{5}{*}{$\begin{array}{l}\text { Slope } \\
\text { (in degree) }\end{array}$} & 21 & $0-6.4$ & 5 \\
\hline & & $6.5-14$ & 4 \\
\hline & & $15-24$ & 3 \\
\hline & & $25-35$ & 2 \\
\hline & & $36-78$ & 1 \\
\hline Drainage & 12 & $0.21-0.94$ & 5 \\
\hline density (in & & $0.95-1.3$ & 4 \\
\hline \multirow{3}{*}{$\left.\mathrm{km} / \mathrm{km}^{2}\right)$} & & $1.4-1.5$ & 3 \\
\hline & & $1.6-1.8$ & 2 \\
\hline & & $1.9-2.9$ & 1 \\
\hline
\end{tabular}

have less groundwater than with mild slope. Rainfall is also affects the potential groundwater zones; the areas that have more rainfall have more groundwater than those with less rainfall. Different LU/LC leave distinctive signatures on groundwater recharge, the areas of water body in the study area produced high groundwater recharge zone.

\section{CONCLUSIONS}

In this study, GIS and MIF techniques have been used for modeling groundwater potential zones by integrating various factors that have been chosen based on the availability of data for Sulaimani Governorate. Traditional data, topographic maps, and satellite imageries were used to prepare the thematic layers of (DEM), soil texture, LU/ LC, slope, rainfall, and drainage density. The resulted map of groundwater recharge zones for Sulaimani Governorate was classified into four zones that had very high potential zone, high potential zone, moderate zone potential, and low potential zone and cover $(1 \%),(14 \%),(79 \%)$, and $(6 \%)$ of the total area, respectively. About $50 \%$ of the high groundwater potential zone were located in Halabja, Rania, and Pshdar districts. The groundwater potential zonation presented here can be applied only for regional studies for the purpose of groundwater development, providing quick prospective guides for groundwater exploration and exploitation, while individual site selection for groundwater development should take into consideration other site-specific conventional ground-truthing methods.

\section{REFERENCES}

[1] V. P. Dinesan, G. Gopinatha and M. K. Ashitha. "Application of Geoinformatics for the Delineation of Groundwater Prospects Zones-a Case Study for Melattur Grama Panchayat in Kerala, India", 2015.

[2] J. Jani. GIS as a tool for modelling groundwater flow. In: "2012 IEEE Symposium on Business, Engineering and Industrial Applications", IEEE, United States, 2012.

[3] A. Ashok, R. Reghunath and J. Thomas. "Mapping of Groundwater Recharge Potential Zones and Identification of Suitable SiteSpecific Recharge Mechanisms in a Tropical River Basin, Earth Systems and Environment", 2020.

[4] R. Gogu, G. Carabin, V. Hallet, V. Peters and A. Dassargues. "GISbased hydrogeological databases and groundwater modelling". Hydrogeology Journal, vol. 9, no. 6, pp. 555-569, 2001.

[5] J. Ghayoumian, M. M. Saravi, S. Feiznia, B. Nouri and A. Malekian. "Application of GIS techniques to determine areas most suitable for artificial groundwater recharge in a coastal aquifer in southern Iran". Journal of Asian Earth Sciences, vol. 30, no. 2, pp. 364-374, 2007.

[6] M. I. Adham, C. S. Jahan, Q. H. Mazumder, M. A. Hossain and A. M. Haque. "Study on groundwater recharge potentiality of Barind tract, Rajshahi district, Bangladesh using GIS and remote sensing technique". Journal of the Geological Society of India, vol. 75, no. 2, pp. 432-438, 2010.

[7] V. Singhal and R.Goyal. "GIS based methodology for groundwater flow estimation across the boundary of the study area in groundwater flow modeling". Journal of Water Resource and Protection, vol. 3, no. 11, p. 824, 2011.

[8] N. S. Magesh, N. Chandrasekar and J. P. Soundranayagam. "Delineation of Groundwater Potential Zones in Theni District, Tamil Nadu, Using Remote Sensing, GIS and MIF Techniques", 2012.

[9] S. Kaliraj, N. Chandrasekar and N. S. Magesh. "Identification of potential groundwater recharge zones in Vaigai upper basin, Tamil Nadu, using GIS-based analytical hierarchical process (AHP) technique". Arabian Journal of Geosciences, vol. 7, no. 4, pp. 1385-1401, 2014

[10] P. K. Ghosh, S. Bandyopadhyay and N. C. Jana. "Mapping of Groundwater Potential Zones in Hard Rock Terrain Using Geoinformatics: A Case of Kumari Watershed in Western Part of West Bengal", 2016.

[11] S. Kumar, B. K. Bhadra and R. Paliwal. "Evaluating the impact of artificial groundwater recharge structures using geo-spatial techniques in the hard-rock terrain of Rajasthan, India". Environmental Earth Sciences, vol. 76, no. 17, p. 613, 2017. 
[12] A. G. Selvarani, G. Maheswaran and K. Elangovan. "Identification of artificial recharge sites for Noyyal river basin using GIS and remote sensing". Journal of the Indian Society of Remote Sensing, vol. 45, no. 1, pp. 67-77, 2017.

[13] H. A. Karim and D. A. Al-Manmi. "Integrating GIS-Based and Geophysical Techniques for Groundwater Potential Assessment in Halabja Said Sadiq Sub-Basin, Kurdistan, NE Iraq", 2019.

[14] C. Serele, A. Perez-Hoyos and F. Kayitakire. "Mapping of Groundwater Potential Zones in the Drought-Prone Areas of South Madagascar Using Geospatial Techniques", 2019.

[15] T. Dar, N. Rai and A. Bhat. "Delineation of Potential Groundwater Recharge Zones Using Analytical Hierarchy Process (AHP), Geology, Ecology, and Landscapes", 2020.

[16] S. Arya, T. Subramani and K. Duraisamy. "Delineation of groundwater potential zones and recommendation of artificial recharge structures for augmentation of groundwater resources in Vattamalaikarai Basin, South India". Environmental Earth Sciences, vol. 79, p. 102, 2020.

[17] M. O. Al-Djazouli, K. Elmorabiti, A. Rahimi, O. Amellah and O. A. Mohammed. "Delineating of groundwater potential zones based on remote sensing, GIS and analytical hierarchical process: A case of Waddai, eastern Chad". GeoJournal, vol. 246, p. 5, 2020.

[18] D. Rawal and A. Vyas. "Application in GIS and groundwater modeling techniques to identify the perched aquifers to demarkate water logging conditions in parts of MEHASAN". ISPRS annals of photogrammetry, Remote Sensing and Spatial Information Sciences, vol. 3, no. 8, pp. 173-180, 2016.

[19] S. K. Singh, M. Zeddies, U. Shankar and G. A. Griffiths. "Potential Groundwater Recharge Zones within New Zealand", 2018.

[20] P. Arulbalaji, D. Padmalal and K. Sreelash. "GIS and AHP techniques based delineation of groundwater potential zones: A case study from Southern Western Ghats, India". Scientific Reports, vol. 9. p. 2082, 2019.

[21] A. M. Rasheed. "Analysis of rainfall drought periods in the North of Iraq". Al-Rafidain Engineering, vol. 18, no. 2, pp. 60-72, 2010.

[22] N. F. Mustafa, H. M. Rashid and H. M. Ibrahim. "Aridity index based on temperature and rainfall data for kurdistan Region-Iraq". Journal of University of Duhok, vol. 21, no. 1, pp. 65-80, 2018.

[23] "United States Geological Survey Online Database", 2019. Available from: https://www.earthexplorer.usgs.gov. [Last accessed on 2019 Sep 20]

[24] S. Zakaria, N. Al-Ansari, Y. T. Mustafa, S. Knutsson, P. S. Ahmad and B. D. Ghafour. "Rainwater harvesting at koysinjaq (Koya), Kurdistan region, Iraq". Journal of Earth Sciences and Geotechnical Engineering, vol. 3, no. 4, pp. 25-46, 2013.

[25] M. L. Collin and A. J. Melloul. "Combined Land-Use and Environmental Factors for Sustainable Groundwater Management". Urban Water, vol. 3, no. 3, pp. 229-237, 2001.

[26] D. N. Lerner and B. Harris. "The relationship between land use and groundwater resources and quality". Land Use Policy, vol. 26, pp. S265-S273, 2009.

[27] H. F. Yeh, Y. S. Cheng, H. I. Lin and C. H. Lee. "Mapping groundwater recharge potential zone using a GIS approach in Hualian River, Taiwan". Sustainable Environment Research, vol. 26, pp. 33-43, 2016.

[28] K. Ibrahim-Bathis and S. A. Ahmed. "Geospatial technology for delineating groundwater potential zones in Doddahalla watershed of Chitradurga district, India". The Egyptian Journal of Remote Sensing and Space Science, vol. 19, pp. 223-234, 2016.

[29] S. L. Martin, D. B. Hayes, A. D. Kendall, and D. W. Hyndman. "The land-use legacy effect: Towards a mechanistic understanding of time-lagged water quality responses to land use/cover". Science of the Total Environment, vol. 579, pp. 1794-1803, 2017.

[30] R. W. Healy. "Estimating Groundwater Recharge". Cambridge University Press, Cambridge. 2010.

[31] H. Bouwer. "Artificial recharge of groundwater: Hydrogeology and engineering". Hydrogeology Journal, vol. 10, no. 1, pp. 121-142, 2002.

[32] "Harmonized World Soil Database, Version 1.2", 2012. Available from: http://www.fao.org/fileadmin/templates/nr/documents/hwsd/ hwsd_documentation.pdf. [Last accessed on 2019 Sep 20]

[33] Food and Agriculture Organization of the United Nations (FAO). "FAO-Geonetwork, Online Database. Digital Soil Map of the World", 2007. Available from: http://www.fao.org/geonetwork/srv/ en/metadata.show?id=14116. [Last accessed on 2019 Oct 18]

[34] K. E. Keese, B. R. Scanlon and R. C. Reedy. "Assessing controls on diffuse groundwater recharge using unsaturated flow modelling". Water Resources Research, vol. 41, no. 6, p. W06010, 2005.

[35] C. Mohan, A. W. Western, Y. Wei and M. Saft. "Predicting groundwater recharge for varying land cover and climate conditions-a global meta-study". Hydrology and Earth System Sciences, vol. 22, no. 5, pp. 2689-2703, 2018.

[36] G. D. Fontana and L. Marchi. "Slope-area relationships and sediment dynamics in two alpine streams". Hydrological Processes, vol. 17, no. 1, pp. 73-87, 2003.

[37] V. M. Rokade, P. Kundal and A. K. Joshi. "Groundwater potential modeling through remote sensing and GIS: A case study of Rajura Taluka, Chandrapur District, Maharashtra". Journal of the Geological Society of India, vol. 69, no. 5, pp. 943-948, 2007.

[38] J. M. Detty and K. J. McGuire. "Topographic controls on shallow groundwater dynamics: Implications of hydrologic connectivity between hillslopes and riparian zones in a till mantled catchment". Hydrological Processes, vol. 24, no. 16, pp.2222-2236, 2010.

[39] S. Selvam, N. S. Magesh, P. Sivasubramanian, J. P. Soundranayagam, G. Manimaran and T. Seshunarayana. "Deciphering of groundwater potential zones in Tuticorin, Tamil Nadu, using remote sensing and GIS techniques". Journal of the Geological Society of India, vol. 84, pp. 597-608, 2014.

[40] D. Greenbaum. "Review of Remote Sensing Applications to Groundwater Exploration in Basement and Regolith". British Geological Survey, Nottingham, United Kingdom. p. 63, 1985.

[41] S. Lakhwinder. "Groundwater Potential Zones, online course", 2018. Available from: https://www.udemy.com/course/ groundwater-potential-zones-using-gis-full-project-arcgis-tutorial/ learn/lecture/12788101\#overview. [Last accessed on 2019 Oct 15] 